\title{
SUFISM IN THE ARCHITECTURAL TYPOLOGY OF THE MELAKA TENGKERA MOSQUE, MALAYSIA
}

\author{
AZIZI BAHAUDDIN \& HAKIMI AHMAD \\ School of Housing, Building and Planning, Universiti Sains Malaysia, Malaysia
}

\begin{abstract}
Islam grew rapidly in the Malay world at the end of the 13th and early 14th centuries AD spread by the missionaries from the Arab countries, India, Iraq and China. It came along with the teaching of Sufism or tasawwuf - the esoteric dimension of Islam supported and complemented by exoteric Sharia (law) practices of Islam. Mosques became the significant landmarks for this religion. The mosque construction development since the time of Prophet Muhammad (pbuh) demonstrated changes. These can be used as thematic resources and theories in artistic architectural language. The mosque architectural typology has contextual values reflecting identities and models needed for the preservation of today's mosque heritage especially in epistemology and conception. The human's roles as caliphs with a Sufism psyche are the most important players in mosque construction. However, there were significant differences in the contemporary mosque typology aesthetical symbols and Islamic images compared to the ones before the 16th century; evident before the Western powers' colonisation of Malaysia. Traditionally the mosque architectural typology was without symbols, minarets or domes. It continued to fade after the colonisation period despite the deeply rooted simple Sufism approach that appeared for four hundred years before. The Melaka Tengkera Mosque built in the 18th century AD, demonstrated this simplicity with a hybrid value and characteristics of Sufism, the regional and Chinese architectural influences. This paper employed a qualitative method specifically in ethnography and phenomenology approaches supported by architectural documentation in emphasising the construction language. It analyses this mosque on the influential values of the Malay and Chinese architectural understanding and the teaching of Sufism. The simplicity reflected the influence of Sufism in the Islamic development among the Malay communities as visible in the mosque in the midst of the changes of cultural affinities.
\end{abstract}

Keywords: Sufism, mosque, ethics, aesthetics and epistemology.

\section{INTRODUCTION}

The term mosque also known as Bayt Allah or God's house (Baitullah) carries the notion of worship and religion and the sole owner of this house is Allah. The concept of Baitullah further validates that the Ka'bah (Haram Mosque) in Mecca and the Al-Aqsa Mosque in Jerusalem were the first global Muslim architecture endowment [1]. The Ka'bah became the qiblah tawhid (direction of the believers) of Muslims throughout the world which went on for more than 15 centuries. It has a universal concept of encompassing and transcending the whole world of life and the hereafter [2]. The consecration of the Baitullah in the form of prayers in a ritual practice of purifying oneself is the nuance of Sufism. This includes dzikir (silently repeated chants), solat (prayers), dzakat (giving alms), recitation of the Quran and tawaf (circumambulating the Baitullah). All these rituals are tied to the historical concept of Nubuwah (prophethood) such as umrah (the non-mandatory Muslim pilgrimage) and hajj (the greater Muslim pilgrimage), the fifth pillar of Islam. In referring to the architecture of Ka'bah, the philosophical values and concept of Sufism go beyond the bounds of reason and feeling. This is due to the Ka'abah privilege of containing the question of reality. The basic principle agreed upon by the scholars regarding the explanation of the fact that the reality is not or cannot be known just by looking at and assessing from the perspective related to the fundamentals. Among them are the Sufism religious experiences and the value of faith in relation to the mosque. So what needs to be looked at is the potential of the mosque in relation 
to its accompaniment, its special features such as its design, its function and its beneficial use in the community. The symbols and substances of the mosque are the semantics statement of the fundamentals that reveal an accepted Sufism fact [3].

\section{HISTORY OF MOSQUE}

At the beginning of the Prophet's (pbuh) life that is, before the Hijrah year, the mosque was not a special building or a particular architectural work. According to a hadith narrated by Sahih Muslim:

Jabir Abdullah Al-Ansary reported that the Prophet had mentioned that the earth has been made sacred and pure and a mosque for me, so whenever the time of prayer comes for any one of you he should pray wherever he is.

Physically, the early building of the Masjid Nabawi (Prophet's Mosque) was a rectangular building using a mud brick construction method. The building had four walls and three covered areas. The roof was supported by columns made of date tree trunks. The first part of the roof sheltered the main space on the wall facing the qiblah. The second covered part was to protect Prophet Muhammad's ( $p b u h$ ) house and his wives on the left side of the main hall. The other side of the roof was located at the front of the mosque where the Sufis (al-suffah) spent their night. The Sufis were poor but educated immigrants. They learned from the Prophet and served him (Fig. 1).

A theory by Caetani quoted in Dickie [4], regarding the construction of Masjid Nabawi as supported by Creswell [5], [6], stated that this building was not a mosque. There were various cultural and welfare works held including military training, politics and economics activities and also a room for homeless people [7]-[9].

\section{DEFINITION OF MOSQUE}

There are some definitions and terms of the mosque that are debated by scholars [10], among which are related to the definition of mosque in terms of syara'/shari'a (law) and urf (general). In the Qur'an, the mosque is expressed in two terms. Firstly, it refers to the Muslims place of worship corresponding to the places of worship of other religions such as church and synagogue [11]-[13]. Like the example in Bayt al-Muqadis, the holy land for the three Abrahamic religions - Judaism, Christianity and Islam. Secondly, the word bayt also shows

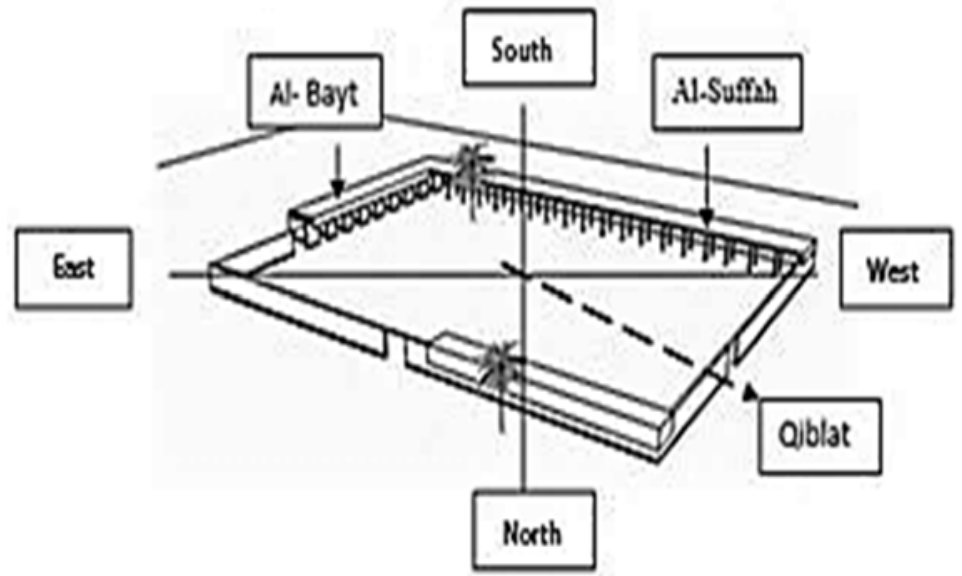

Figure 1: Masjid Nabawi complex [14]. (Source: Creswell, 1969.) 
two meanings. Firstly, the word bayt Allah refers to Baitullah of the Haram Mosque. Secondly, the word bayt refers to the Prophet's family home, as in the word of Allah (alAhzab: 33):

And stay in your homes and do not go about displaying your allurements as in the former Time of Ignorance. Establish Prayer, give dzakat, and obey Allah and His Messenger. Allah only wishes to remove uncleanness from you, $\mathrm{O}$ members of the (Prophet's) household, and to purify you completely [14].

This verse connotes tasawuf teaching of purifying the soul, a nuance in Sufism characterized by ahlul-bayt (people of the house). The word bayt also refers to the nest of animals (e.g.: bee nests (Ayat An-Nahl, 16:68) and spider's nest (Ayat Al-Ankabut, 29:41) and in general term (Fig. 2).

\section{MOSQUE AESTHETIC}

There are important aesthetic characteristics of the mosque that can influence the ethics of Sufism [15], [16]. The known two aesthetic concepts are based on formal aesthetic and symbolic aesthetic. A formal aesthetic consists of appearance, proportion, scale, complexity, novelty and illumination aspects [15], [17]. A formal structure of aesthetic framework according to the aesthetic related science, the objects state more objectively of their own aesthetic symbols through image communication, language and their success is determined by the audience who enjoys it [18]. Hence structuralism is related to the existing relationship between concepts or symbols relating to local culture and society [19]. The symbolic aesthetics, on the other hand, comprise the dimensions of denotative and connotative meanings. This statement is parallel to [20] in connection with the socio-semiotic concept described by [19] that connects the denotative signs such as images, functions and styles of architecture; while the connotative signs are related to local culture [20]. The semiotic theory by De Saussure [21] divided the semiotics into two parts (dichotomy) of the signifier and the signified. The marker is seen as physical form (mosque) and can be known by the form of architectural work. The sign is seen as the meaning or tasawwur (worldview) revealed through the concept, function or value contained in the work of architecture. The meanings can be seen in the components of the Melaka Tengkera Mosque.

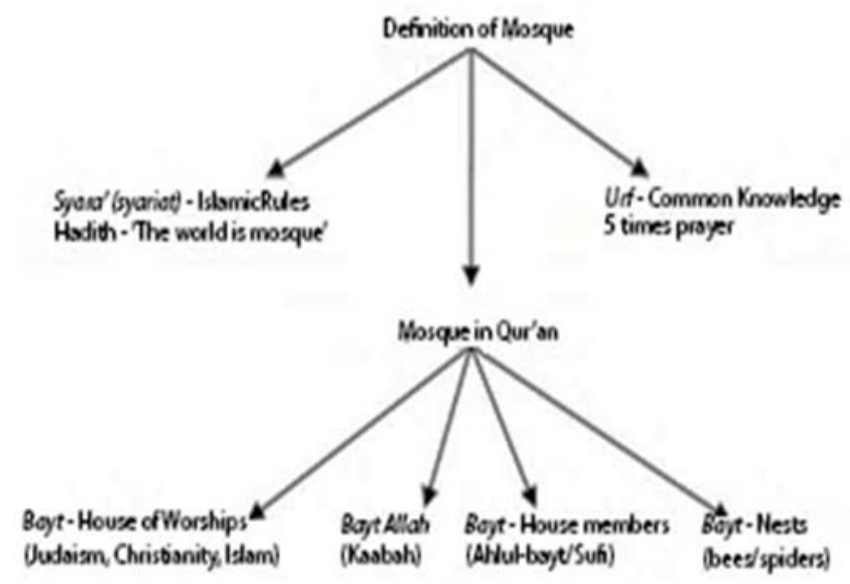

Figure 2: Mosque according to syara' and urf. 


\section{MOSQUE OF MELAKA}

Melaka is one of the fourteen states in Peninsular Malaysia (Fig. 3). It is located along the Straits of Melaka and was established in the fifteenth century. Melaka or 'Malacca' has perhaps the most dominant position in Malaysian history.

There are two distinctive categories of historical mosques in Malaysia Islamic architecture. Firstly, is a vernacular style that was believed to be formed during the early influence of Islamic religion that came to the Malay Archipelago. The second architectural style was brought by the Western influence and categorised as Classical Islamic forms. This style includes domes, arches and minarets, believed to be originated from the Moghul and Islamic Bengal [23]. This style was only first built in Southeast Asia in the nineteenth century [24]. Vernacular mosque in this region was designed without domes but instead the high pitch roof formed the most dominant feature. There are two types of vernacular mosque found in Malaysia.

The first type has a tiered pyramidal roof, sometimes referred to as the meru (mountain) roof mosque and the second type has a similar characteristic of traditional dwellings with a gabled roof. Amongst the two types the former is the earliest typology in Malaysian history. On the other hand, there are two categories of the vernacular mosque, the traditional influence and regional influence. The traditional influence usually reflects the strong influences of the Malay house but the regional influence mosque in Malaysia is similar to that of the old mosque built in many part of Indonesia [25]. This is true in the case of the Melaka Tengkera Mosque. The Melaka Tengkera Mosque architecture style had a direct influence from Java. It was brought through Sumatera during the years of Dutch occupation of Melaka when free movement of men and ideas throughout the Dutch empire were allowed. It introduced new concepts into the peninsula [26]. The Javanese style spread across the Malay Peninsula replacing the old timber wall with masonry wall, on stilts with a low perimeter stone wall, giving rise to the Melakan style.

In the 15th century AD Malay World, the Sufi institutions of pesantren (huts) by walisongo (Indonesia revered Islamic saints) were established. It is said that Maulana Malik Ibrahim was the first Sufi figure to build a cottage in Gresik, Java [27]. The Demak Grand Mosque was built by the Walisongo Sufi in 1479 [28], but it was believed to have already gone through numerous renovations and repairs (Fig. 4) and understood to be the oldest mosque in Southeast Asia. The architecture of this mosque could have become the typology that influenced the mosque architecture throughout the Malay Archipelago. The mosque is placed in the centre of a walled area and surrounded by funerary garden or cemetery.

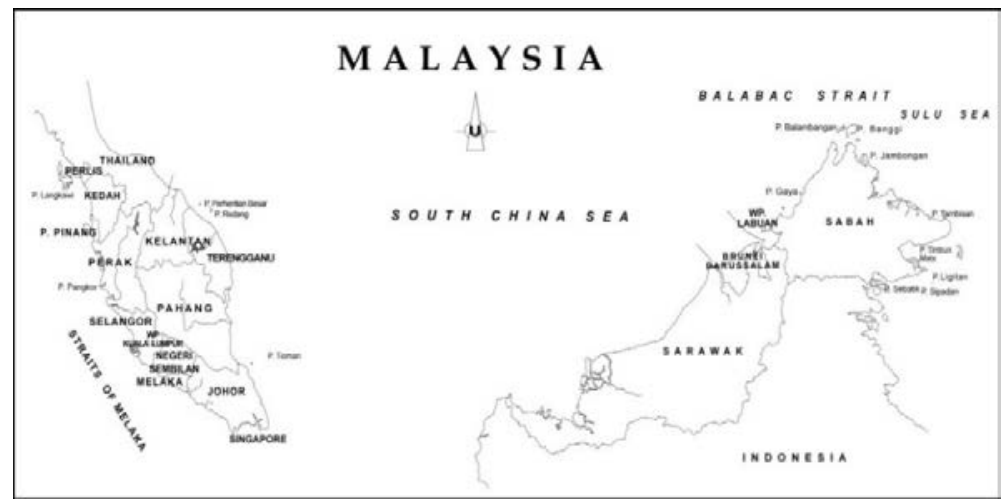

Figure 3: Peninsular Malaysia [22]. 


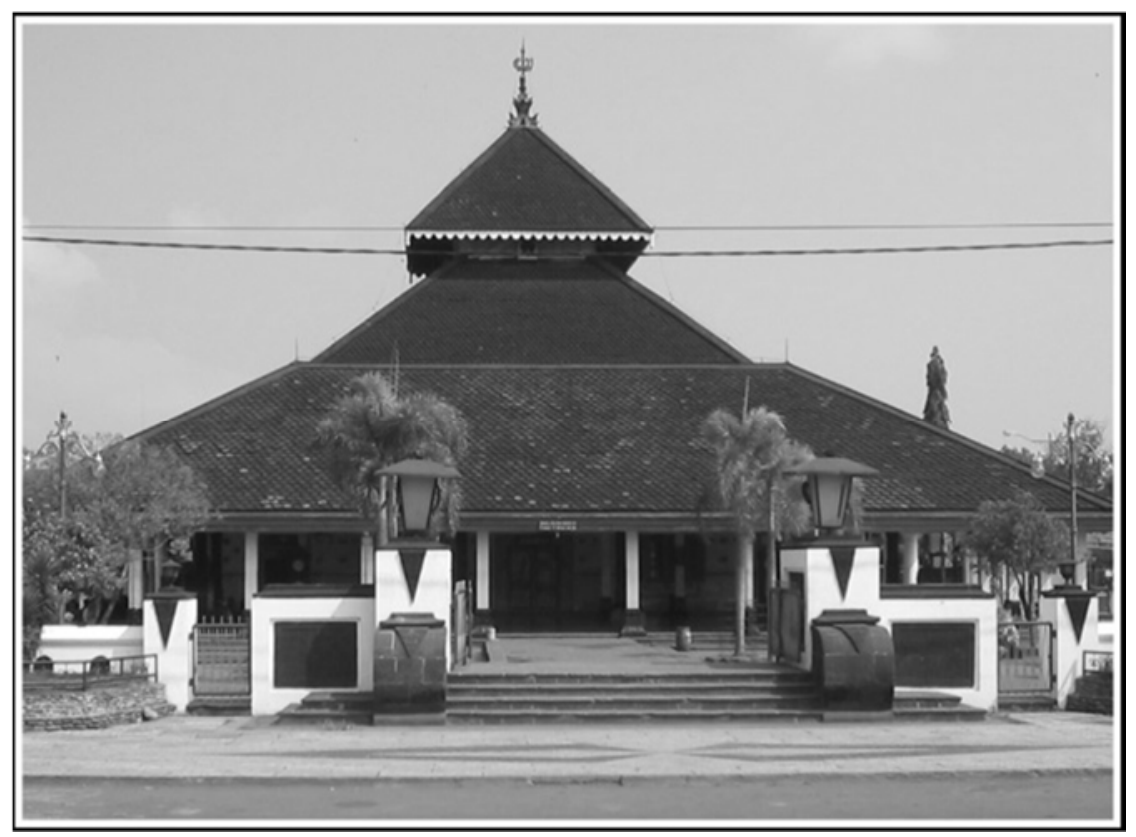

Figure 4: Demak Grand Mosque, Indonesia [29].

\section{MELAKA TENGKERA MOSQUE}

The Melaka Tengkera Mosque (Fig. 5) is considered among the oldest mosques in Melaka and was built around 1728 [30], during the Dutch colonial era. The mosque is located in the Tengkera district at ten kilometres to the northwest of old Melaka town. It was once the State Mosque of Melaka. Originally, the mosque was made of timber with the roof made of palm leaves, and pillars from belian/ulin wood (Borneon ironwood) imported from Kalimantan, Indonesia. The mosque was renovated twice in 1890 and in 1910.

This surviving traditional Malay mosque in Melaka today illustrates the architecture of the Malay world with its uniqueness in its construction technology and climatic approach; integrating with the space function and elements of the mosque architecture are vital in the mosque design [8]. The mosque main reference was from the Masjid Nabawi design in Medina [31], [32], that feature space function and components such building orientation to qiblat, entrance gate, wudhu (ablution) area, serambi (verandah), prayer hall, mihrab (niche area to indicate qiblat), mimbar (sermon podium), main roof design and minaret. The shape of the mosque is a square $18 \times 18$ metres, with small additional shapes attached to it. The mosque is divided into several areas of the main prayer hall, mihrab, serambi and the utility room. The main prayer hall is rectangular in shape, measuring $15 \times 12$ metres. The serambi surrounds the main prayer hall with a width of three meters throughout (Fig. 6). The serambi, a transitional space between outside and inside, is elevated at $900 \mathrm{~mm}$ from the ground level with a series of steps at each entrance. The serambi and the prayer hall are at the same floor level. The floor for the prayer hall and the serambi is of $200 \times 200 \mathrm{~mm}$ ceramic tiles.

In general, the structural system of Tengkera Mosque (Fig. 7) is a combination of post and beam and load bearing wall structures. The floor of the mosque is also raised, and rest on a brick wall base. The roof is staggered into three main sections, one on top of the other. 


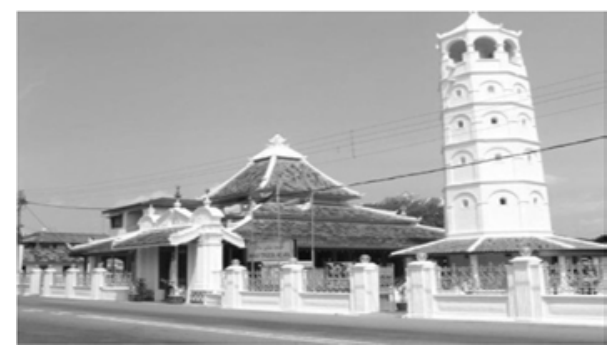

Figure 5: Melaka Tengkera mosque.

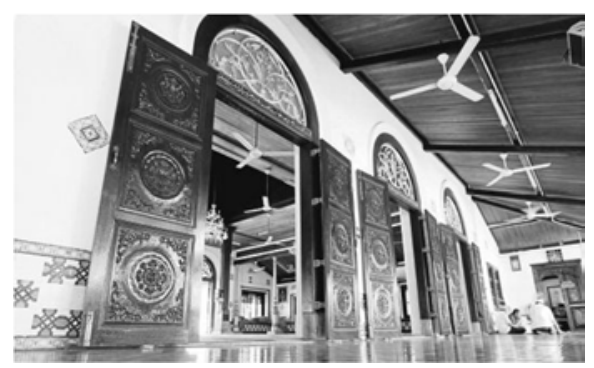

Figure 6: Serambi (verandah).

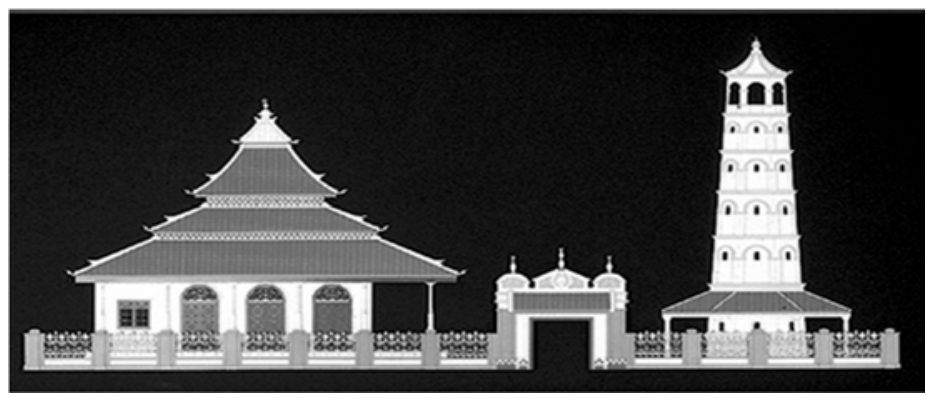

Figure 7: Melaka Tengkera Mosque elevation.

The upper segment of the roof is set on the steepest angle among the three, at 50 degree. The middle roof section is set at a slightly increased angle of 28 degrees (Fig. 8). The lower roof section covers the serambi area, supported using masonry walls of the prayer hall and the columnar outer perimeter. This is the shallowest of angles among the three sections of the roof, set at 19 degrees. The prayer hall is seen as a double volume space at the centre and single volume at the rest of the surrounding spaces, which had a loft on the upper part of the ceiling. The loft or attic is bordered with a series of timber balustrade railings.

During the early stage of the Dutch colonisation and their strengthening position in Melaka (1641 to 1700), the construction of religious buildings including mosques was allowed. As the Chinese were known to have superior knowledge and skill of masonry construction, their involvement was much sought after. Eventually, their traditional 


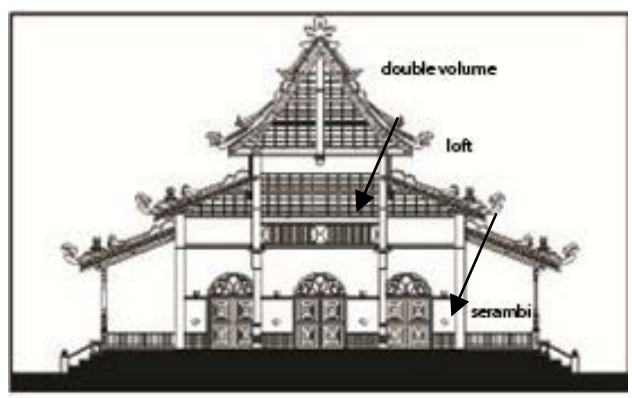

Figure 8: Tiered roof.

construction techniques and systems were adopted. This kind of assimilation was one of the common styles of Chinese roof treatment at the roof ridge observed in the roof treatment of Tengkera mosque (Fig. 9) seen in Chinese temple; a cut and paste technique of decoration using broken ceramic pieces. The ridge of Tengkera Mosque was decorated similar to the roof of Chinese temple [33]. This mosque was renovated in early 1910 and the responsible craftsmen who designed the ridge had added these Chinese architectural elements.

The minaret stands to the east of the main building outside of the main entrance of the mosque. It is detached from the main building (the mosque) by about three meters and is located along an axis of the mosque. A pitched roof covering a pathway to the minaret connects both buildings. The minaret of the mosque is six storeys tall and octagonal in plan (Fig. 10).

The wudhu (ablution) pool located to the north of the mosque, was built parallel to the main building and was roofed individually (Fig. 11). The roof is supported by a series of steel columns full of precast ornaments. The cemetery lies to the far east of the minaret rather than being adjacent to the qiblah wall. Most of the graves used timber and laterite stones which suggested that these graves could have been in existence since the early 18 th century as these were the two most common materials used for grave stones during those periods [34]. These facts implied that the mosque was built as early as 1728 and it was common to have a cemetery allocated in the same compound when the construction of the mosque took place.

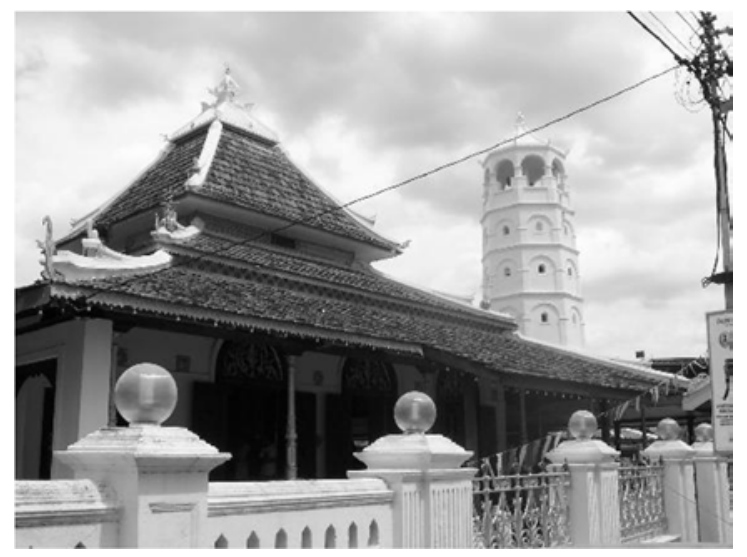

Figure 9: Wavy ridge roof. 


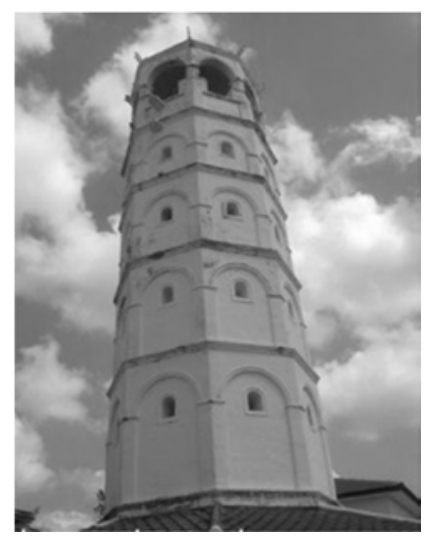

Figure 10: Tiered pagoda minaret.

Imam al-Ghazali in Jawahir al-Quran, supported by Sheikh Abdul Samad al-Falimbangi in the Saurus Salikin, stated that Islamic Science consists of shari'a knowledge, tariqat and haqiqat (ultimate truth) [35]. Some scholars argued that the number of roofs over the mosque building such as the Melaka Mosque symbolises levels in the teachings of tasawwuf, namely of shari'ah, tariqat (a concept for the mystical teaching and spiritual practices), haqiqat (ultimate truth) and maqrifat (the truest and highest level of knowledge); they considered such a building of Masjid Demak of having four levels, with a mustaka symbolising the nature of self-submission to Allah as the fourth level (Fig. 12). When it comes to a strong level of belief, a man is considered a wise person for the reasons related to semantics and through suluk that is related to the divine nature [36]. Thus, shari'a is the question of fiqah (theory of Islamic law) with the essence of maqrifat while tariqat is the process of understanding of the shari'a to the understanding of haqiqat. This understanding is the value of Sufism that many learned in the science of irfan (knowledge and wisdom) or tasawuf.

\section{TASAWWUR - SUFISM WORLDVIEW}

There are two important values to understand found in this mosque. Firstly, the intrinsic value - value contained in its beauty and secondly, the extrinsic value - value seen from the outside. For intrinsic value it can usually be perceived and understood from the heart by the recipients, while the extrinsic value can be viewed directly. It means that the value is solely from the psychological reality that must be firmly distinguished of its usefulness, because it is in the

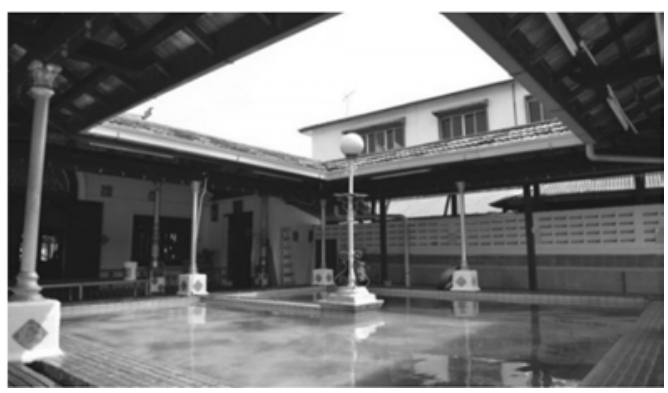

Figure 11: The wudhu pool. 


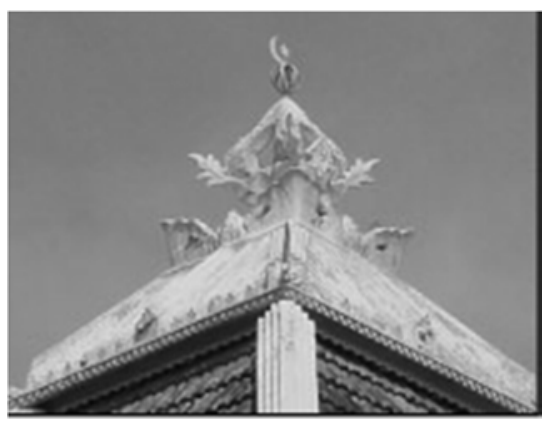

Figure 12: Mustaka, meru roof.

human soul (tasawuf) and not in itself. The person's value is considered to exist in an object until it is proven of its truth. The value that exists distinguishes between subjective and objective values. Beauty has a very broad dimension of interactions between human and objects (mosques), among humans and between humans and God, and within humans who interact. Disclosure of beauty in artwork is based on a particular motivation and with a particular purpose. That motivation can be the experience or the reality of changing values in society, the glory of Allah, and many others. The purpose is of course seen in terms of the value of human life, human dignity, and humanity's use in nature.

Tasawuf is in accordance with the definition of muktabar (venerated person practicing shari'ah) based on the hadith Ihsan of "worshiping as if to see Allah swt" [37], [38]. There are differences in tasawwur related to the terms, meaning and direction related to ethics and morals because they are synonymous with the meaning of tasawuf or Sufism. Although it involves attitude, good and bad deeds, in connection with the construction of the mosque, the philosophy of tasawuf is seen as relevant in the pursuit of mardhatillah (seeking Allah's approval) as the ultimate goal. The mosque needs to place a balanced concept between materiality and spirituality [39]. The concept of tazkiyah (purification of the soul) is able to solve the problem of human development and the administration of the mosque as a whole. Ethical values that are not surficial Sufistic are relative and subjective [40]. Therefore, ethics may change according to the worldview and environment.

There are five ethical values of Sufism namely fardhu (commanded), sunnah (recommended), mubah/harus (indifferent), makruh (disapproved) and haram (forbidden) [41]. It is obligatory for Muslims to obey the command of Allah and to safeguard the purity of mind and spirit. It is forbidden to worship other than Allah and to associate Him with something else. It is recommended to do good deeds for rewards such as to make selfrealisation, to have good relationships with others, to help others and to respect for nature and other humans. Staying away from vain deeds is makruh like wasting time with unnecessary things such as seeing, hearing, saying with desires that will lead to doing forbidden acts. These values are the concern of the Sufi in training and purifying the heart.

There are two intentions (mission and vision) in relation to the philosophy of the mosque. One is to achieve the value of the worldly mission (secular) and the vision of the hereafter (sacred). World mission values relate to culture with fiqah such as in the time of Prophet Muhammad (pbuh). The value of the secular mission is to mix or separate the affairs of the hereafter from the aesthetics of the world affairs (dualism); and the value of the sacred vision is related to the knowledge of Prophethood of al-Qur'an and Hadith as well as good ethics (Fig. 13). In addition, there is a question of sacred ethics and secular aesthetics of the mosque 


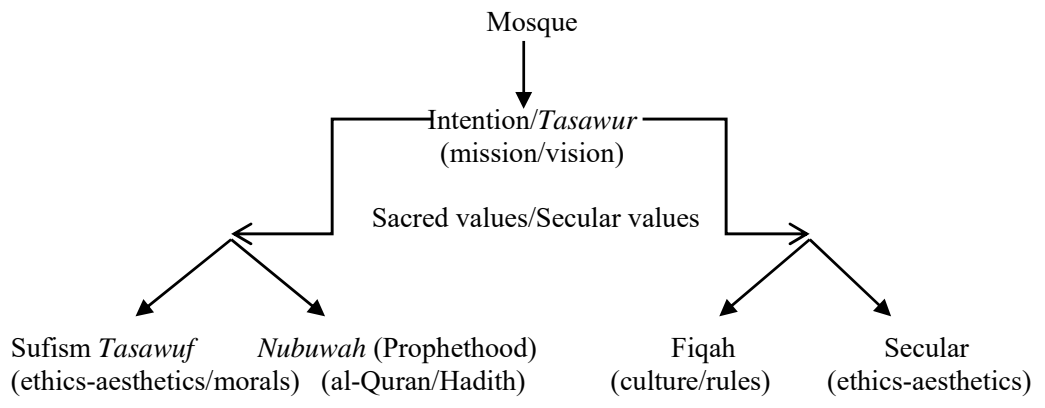

Figure 13: Mosque tasawur - mission/vision.

in relation to the intention (mission / vision) and sincerity rather than the implementation of interactive rituals. Thus, the value of sincerity plays an important role in controlling the affairs of the heart and morality in relation to the meaning of the mosque, nature, man and Allah. The features of Islamic legacy on the history of a race should be sought not only on physical things or things that are visible and easily visible to the eyes, but to those things which are hidden from the observed view, for example the thoughts or tasawur of a race contained in the language of their lives. The study of history should also be addressed in the spiritual matter according to the Qur'an and Hadith against the soul of the community [42], [43].

This paper aims to re-evaluate the understanding, objectives, artistic and aesthetic values of Islam in general and in the architecture of the Melaka Tengkera Mosque. The Islamic arts that have been formed and developed for centuries are facing the threat of the process of acculturation and domination of the modern-day modern art values. Evaluation was made on the understanding of Sufism according to the perspective of Islamic cosmology.

The conclusions from the discussion explain the value and the essence or the spiritual complement the mosque physical value.

\section{CONCLUSION}

It is like a body and a spirit that play a role together. Tasawuf is one of the basic things that form the physical development framework of the mosque besides knowledge and fiqah [44]. Human beings are the important actors as well as the core players of the mosque's process of building and rebuilding. Hence the relationships of ethical and aesthetic roles are seen as important because the dimensions that the humans perceive will determine their way of life on the right path [45], as demonstrated in the combination of the fiqah and tasawwur found in the Melaka Tengkera Mosque.

\section{ACKNOWLEDGEMENT}

The authors would like to thank Ministry of Higher Education of Malaysia for providing this Research University Individual Grant Scheme (RUi - 1001 / PPBGN / 8016011) and for providing facilities to carry out the work to support this study.

\section{REFERENCES}

[1] Othman, R., Menelusuri Jejak Kegemilangan Wakaf: Di Mana Peranan Pentadbir. Presented at Seminar Pragmatist 2 - Perkongsian Amalan Terbaik dalam Pengurusan Universiti, Universiti Putra Malaysia: Serdang, 2015. 
[2] Bakar, O., Pengaruh Globalisasi Terhadap Peradaban. Jurnal Peradaban. Universiti Malaya: Kuala Lumpur, pp. 1-23, 2008.

[3] Shihab, M.Q., Membumikan Al-Qur'an, Mizan: Bandung, pp. 10-15, 1992.

[4] Dickie, J. Allah and Eternity: Mosques, Madrasah and Tombs. Architecture of the Islamic World, ed. G. Michell. Thames \& Hudson Ltd: London, pp. 15-47, 1995.

[5] Creswell, K.A.C., A Short Account of Early Muslim Architecture, Librarie du Liban: Beirut, p. 12, 1958.

[6] Creswell, K.A.C., A Short Account of Early Muslim Architecture II, UK: Clarendon Press: Oxford, pp. 83-87, 1968.

[7] Grabar, O., Art and Culture in the Islamic World. Islam: Art and Architecture, eds M. Hattstein and P. Delius. Tandem Verlag GmbH: Konigswinter, pp. 34-57, 2004.

[8] Mohamad Rasdi, M.T., The Traditional Mosque: The Architectural Heritage of the Malay World, UTM: Skudai, pp. 40-55, 2000.

[9] Frishman, M. \& Khan H-U., The Mosque: History Architectural Development \& Regional Diversity, Thames \& Hudson Ltd.: London, pp. 9-10, 1994.

[10] Mohamad Rasdi, M. T., Rethinking Islamic Architecture, Strategic Information and Research Development Centre: Petaling Jaya, pp. 1-191, 2010.

[11] Verkaaik, O., Designing the 'Anti-Mosque': Identity, Religion and Effect in Contemporary European Mosque Design. Social Anthropology, Wiley Online Library. May 2012.

[12] Hattstein, M. \& Delius P., Islam : Art and Architecture. eds M. Hattstein and P. Delius. Tandem Verlag GmbH: Konigswinter, pp. 8-33, 2004.

[13] Bosworth, C.E., van Donzel, E., Lewis, B. \& Pellat C., The Encyclopedia of Islam, Vol. VI , EJ. Brill: Leiden, p. 644, 1991.

[14] Othman, S. \& Mohamad M., Ahlul-Bait (Keluarga) Rasulullah SAW dan Kesultanan, Cresent News (K.L.) Sdn. Bhd: Kuala Lumpur, pp. 5-25, 2009.

[15] Nasar, J.L., Urban Design Aesthetics: The Evaluative Qualities of Building Exteriors. Environment and Behaviour, 26, pp. 377-401, 1994.

[16] Steinitz, C., Meaning and Congruence of Urban Form and Activity. Journal of the American Institute of Planners, 34, pp. 233-248, 1968.

[17] Lang, J., Understanding Normative Theories of Architecture. Environment and Behaviour, 20, pp. 601-632, 1988.

[18] Hughes, P., From Nostalgia to Metatheory: Researching Children's Relationship with the Media. Journal of Contemporary Issues in Early Childhood. 2(3), pp. 354-367. 2001.

[19] Hawkes, T., Structuralisme and Semiotics, Routledge: London, pp. 8-19, 2003.

[20] Barthes, R., The Semiotic Challenge, Basil Blackwell: London, pp. 197-201, 1988.

[21] De Saussure, F ., Course in General Linguistics, University of Geneva: Geneva, pp. 65-70, 1916.

[22] Map of Malaysia., Department of Survey and Mapping Malaysia. www.jupem.gov.my. Accessed on: 19 Jan. 2018.

[23] Mohd Ali, K., Architecture: Unity of the Sacred and the Profane. Islamic Civilization in The Malay World, Dewan Bahasa dan Pustaka and the Research Centre for Islamic History, Art and Culture: Kuala Lumpur, pp. 245-277, 1997.

[24] O’Neill, H. South East Asia., The Mosque History Architectural Development Regional Diversity, eds M. Frishman and H.U. Khan. London: Thames \& Hudson, pp. 225-240, 1994.

[25] Ahmad, A.G., The Architectural Styles of Mosque in Malaysia: From Vernacular to Modern Structures. Symposium on Mosque Architecture, Vol. 2, The Historic and 
Urban Developments of Mosque Architecture, King Saud University, Saudi Arabia: Riyadh, pp. 147-163, 1999.

[26] Vlatseas, S., A History of Malaysian Architecture. Longman, Singapore Publishers Pte Ltd.: Singapore, pp. 39-51, 1990.

[27] Bashah, A.H., Wali Songo: Dengan Perkembangan Islam Di Nusantara, , Al-Kafilah Enterprise: Kota Bharu, pp. 1-149, 1996.

[28] Ali, Z., Islamic Art in Southeast Asia - 830 A.D.-1570 A.D, Dewan Bahasa dan Pustaka: Kuala Lumpur, pp. 61-70, 1994.

[29] Gunawan, B.I., Demak Grand Mosque. https://womenindonesia.blogspot.my/search/ label/Traveling. Accessed on: 19 Jan. 2018.

[30] Ahmad, D.H.M., Sejarah Ringkas Masjid-Masjid Negeri Melaka. Majlis Agama Islam Melaka: Melaka. www.maim.gov.my/index.php/my. Accessed on: 19 Jan. 2018.

[31] Omer, S., Studies in the Islamic Built Environment, Kuala Lumpur Research Centre: International Islamic University Malaysia Press: Kuala Lumpur, 2nd ed., pp. 111-145, 2014.

[32] Syed Ariffin, S.A.I., Architectural Conservation in Islam. Universiti Teknologi Malaysia Press: Skudai, pp. 81-108, 2005.

[33] Nasir, A.H., Architecture of the Old Mosques in Southeast Asia. Penerbit Universiti Kebangsaan Malaysia: Bangi, pp. 1-196, 1995.

[34] Nor, R., Personal Communication, 21 Jul. 2000.

[35] Mohd Yusof, M.R., Tarekat Naqsyabandiah Al-Khalidiayah Di Malaysia-Satu Analisis Kritis Berdasarkan Al-Quran \& Al-Sunnah. Darul Fikir Sdn. Bhd.: Kuala Lumpur, pp. 1-214, 2004.

[36] Nakula, A.M., Senibina Islam - Aplikasi di Malaysia, Pustaka Dian Press: Kota Bharu, pp. 1-93, 1982.

[37] Al-Attas, S.M.N., The Positive Aspect of Tasawuf: Preliminary Thoughts on an Islamic Philosophy of Science. International Institute of Islamic Thought and Civilization (ISTAC): Kuala Lumpur, pp. 1-12, 1981.

[38] Al-Attas, S. M. N., Islam dan Secularism. International Institute of Islamic Thought and Civilization (ISTAC): Kuala Lumpur, pp. 100-131, 1993.

[39] Awang, R., Falsafah Sains dan Pembangunan ke Arah Dimensi Baru. Penerbit University Teknologi Malaysia: Skudai, pp. 1-40, 2003.

[40] Ahmad, K., Studies in Islamic Economics (Perspectives of Islam), International Centre for Research in Islamic Economics, King Abdul Aziz University: Jeddah, pp. 20-40, 1980.

[41] Syed Ariffin, S.A.I., Architectural Conservation in Islam, Case Study of the Prophet's Mosque. Penerbit Universiti Teknologi Malaysia: Skudai, pp. 130-150, 2005.

[42] Mohamad Rasdi, M.T., Krisis Pemikiran Seni Bina Malaysia, Penerbit University Teknologi Malaysia: Skudai, pp. 60-65, 2011.

[43] Al-Attas, S.M.N., Islam dalam Sejarah dan Kebudayaan Melayu. UKM: Bangi, pp. 42-45, 1972.

[44] Muhammad Syukri Salleh, M.S., Falsafah Pembangunan Kapitalis dan Marxis: Dua Falsafah dalam Satu Paradigm, Visi 31, pp. 17-18, Apr.-Jun., 2000.

[45] Yusof, R., Asas-asas Sains Sosial daripada Perspektif Sosiologi. Dewan Bahasa dan Pustaka: Kuala Lumpur, 1996. 